\title{
Development of Innovative Chemistry Practicum Based on Multimedia Senior High School Class XI Semester II Integrated Character Education According to the 2013 Curriculum
}

\author{
Herry Purwanto Panjaitan ${ }^{*}$, Ramlan Silaban², Iis Siti Jahro ${ }^{3}$, Wesly Hutabarat ${ }^{4}$, Ida \\ Duma Riris ${ }^{5}$, Ajat Sudrajat ${ }^{6}$, Nurfajriani ${ }^{7}$ \\ 1,2,3,4,5,6,7 Chemistry Education, Faculty of Mathemathics and Natural Science, Universitas Negeri Medan, \\ Indonesia \\ herry_purwanto_p@yahoo.com
}

\begin{abstract}
This study aims to determine the suitability, feasibility, and integration of character and psychomotor in class XI senior high school chemistry practicum guidebooks used in schools with BSNP criteria. This study is a research and development model modified from the Borg \& Gall model. In this study, there are 5 stages carried out; The needs analysis stage, the development stage, the validation stage, the revision stage and the product trial. This research trial was conducted at the Satrya Budi Perdagangan private high school, Simalungun regency. The sample in this study was taken by using cluster random sampling technique. Data collection techniques used BSNP questionnaires, test instrument sheets, character assessment observation sheets, and psychomotor assessment observation sheets. Research result; (2) The innovative chemistry lab guide based on multimedia for class XI Semester II is integrated with character education according to The 2013 curriculum is included in the valid and feasible category for use on average (3) The practicum guide developed can develop the character education values of students, this can be seen from the increase in the attitude value of students before and after using an innovative chemistry-based practical guide multimedia class XI senior high school Semester II integrated character education according to the 2013 curriculum. (4) There are differences in the learning outcomes of students who use an innovative chemistry practicum guide based on multimedia high school grade XI Semester II integrated character education according to the 2013 curriculum with students who use a chemistry lab guide for students with sig. $<\alpha(0.000<0.05)$ (5) There are differences in the attitude (character) and psychomotor (skills) values of students who use innovative chemistry lab guides based on multimedia high school grade XI Semester II integrated character education according to the 2013 curriculum with students using chemistry lab guide guide for students.
\end{abstract}

Keywords

development of practicum guides; innovative chemistry practicum; character education; 2013 curriculum, and Borg \& Gall Models

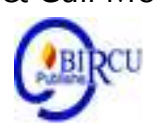

\section{Introduction}

Learning development as a systematic way to identify, develop, and evaluate a set of learning materials and strategies with the intention of achieving certain goals (Twelker, Urbach, \& Buck, 1972). According to Suparman (1991) learning development as a systematic process includes problem identification, strategy development and instructional 
materials, and evaluation of instructional strategies and materials in achieving learning objectives effectively and efficiently. Innovation is a new change in direction of improvement that is different or different from the previous one, which is done deliberately and planned (not accidentally) (Robbins, 1994). Innovation in learning can be defined as learning that uses new ideas or techniques/methods to carry out learning steps, so as to obtain the desired progress of learning outcomes (Rogers, 1995).

Efforts to build the nation's character should be optimized and made as a top priority, because of the many bad social facts that are happening everywhere. Among them, the phenomena of anarchist attitudes, coercion of will, social conflicts, riots and violence, student and student brawls, promiscuity accompanied by pornography and porno-action, sex crimes, socio-economic inequality, trade monopolies and conglomeration, increasingly damaged natural environment, corruption, and so on. These facts indicate a serious threat to the future of the nation (Kaimuddin, 2014). Various learning innovations to improve student achievement are needed so that learning takes place optimally. Therefore, learning must be innovative in accordance with the subjects taught, in increasing student learning achievement. Learning innovation, especially in producing practicum guides, must be in accordance with the curriculum used (Nahadi, 2009). This is in line with research conducted by Jahro and Susilawati (2008) where the implementation of practicum activities both in quantity and quality is not optimal.

The use of learning media can also support and attract students' interest in participating in learning activities. Therefore we need an application program that can make these lessons interesting and interactive so that students are interested in taking these lessons (Arends, 2008). The use of media in learning must be in accordance with the needs so that the media used matches the material presented. The basic principle of selecting learning media that must be considered is that the media must be related to the topic of learning, according to the age and maturity level of the learners, must be precise in content, and can be accepted elsewhere for the same lesson (Akere \& Afolabi, 2012). This is in line with research conducted by Nurfajriani (2016) with the Development of a Science Learning Module Based on the 5E Learning Cycle which received a positive response from students. This means that development is needed to motivate students not only in knowledge but also in character. Several previous studies that have attempted the development and innovation of teaching materials such as Christianto (2016), which examined the Multimedia-Based Interactive Practicum Guide, provided higher learning outcomes for students compared to using practicum guides in schools. Anggraini (2016) examines the Development of Innovative and Interactive Integrated High School Practicum Guides, Discovery Learning (Discovery Learning) on Elemental Chemistry can increase student learning outcomes by $39 \%$. Other studies have also shown that the use of interactive multimedia instructions shortens the completion time of a given experiment and reduces laboratory errors (Burewicz \& Miranowicz, 2006).

In the learning process activities in the classroom, a lecturer must use learning media. The development of technology, communication and information, especially the internet has become a demand for teachers in Indonesia to be able to use it as a source of positive learning media in supporting teaching and learning processes (Prasasti, 2019). According to Syakur (2020) the development of information and communication technology in the Industrial 4.0 era has had a great influence on the teaching and learning process in the world of education, especially in higher education and universities. In the industrial era 4.0, digital technology can have a negative impact on education if its use is not appropriate. 


\section{Research Methods}

The population in this study were all class XI senior high school students in Simalungun Regency. The sample in this study was taken using the cluster random sampling technique so that the research sample at the product-limited trial stage were students of class XI Sains Satrya Budi Perdagangan private high school which consisted of two classes, the first as the experimental class and the control class. The development of this practicum guide uses a type of research and development that is modified from the Borg \& Gall model.

The procedure in this study consisted of 5 (five) stages, namely; Needs Analysis Stage, Development Stage, Validation Stage, Revision Stage, and Product and Testing Stage. (1) Needs Analysis Stage, at this stage the researcher analyze three chemistry lab guides for class XI semester 2 . The three chemistry lab guides are analyzed to find out potential problems, then collect data information for the development of innovative chemical lab guide products with integrated characters to be developed based on the syllabus. to produce practicum guides that meet the BSNP eligibility standards. (2) Development Stage, At this stage the researcher develops an innovative chemistry practical guide integrated character education based on the analysis carried out in stage 1. (3) Validation stage, At this stage, the character education integrated innovative chemistry lab guide that has been developed is assessed for its feasibility level, presentation, material, language and media. Where at this stage the assessment is carried out by 10 respondents; 2 chemist lecturers and 8 high school chemistry teachers. (4) Revision Stage, at the revision stage, improvements or revisions is made to the chemistry practicum guide. Based on the results of the validation, the practicum guide was revised in order to produce a better chemistry lab guide. (5) Products and Trials, after passing the field test stage, the main product is refined so that an effective, efficient, interesting and character-integrated class XI senior high school semester 2 lab guides is produced according to the 2013 Curriculum to be used in the learning process.

Data collection techniques in this development research are: (1) the test instrument is in the form of multiple choices before being tested for validity, reliability, difficulty level, difference power, and distructor. (2) Before testing the hypothesis, the data prerequisite test is conducted, namely the data normality test and the homogeneity test. (3) Data on the effectiveness of using a practicum guide can be seen from the cognitive aspect by comparing the pretest and posttest scores. (4) Data on the efficiency of using the practicum guide for acid and alkaline solutions use the time comparison before and after the use of the practicum guide. (5) The attractiveness of the practicum guide on acid and alkaline solution material is taken using an attractiveness questionnaire. (6) The data on learning outcomes using a practicum guide can be seen from the cognitive aspect by comparing the pretest and posttest scores. (7) The character data for the use of the practicum guide is seen using a character questionnaire. (8) The data on the skills of using the practicum guide were seen using a skills questionnaire. (9) Hypothesis testing used Independent Sample Ttest two parties in the SPSS 21 for windows program.

\section{Discussion}

The existing guidebook (school handbook) was analyzed as many as 3 manuals. Then the results of the analysis were developed and tested by 10 respondents consisting of 2 lecturers and 8 teachers. The response assesses the feasibility of the content, the feasibility of presentation, the material, the media, and the language used. The indicator of 
assessment by respondents used is a modification of the BSNP. The following graph is produced from the research.

\subsection{Content Eligibility}

The average value of the results of the respondents' assessment (lecturers and teachers) on the feasibility aspect of presenting an innovative chemistry practicum guide based on multimedia high school grade XI integrated character education according to the 2013 curriculum can be seen in figure 1.

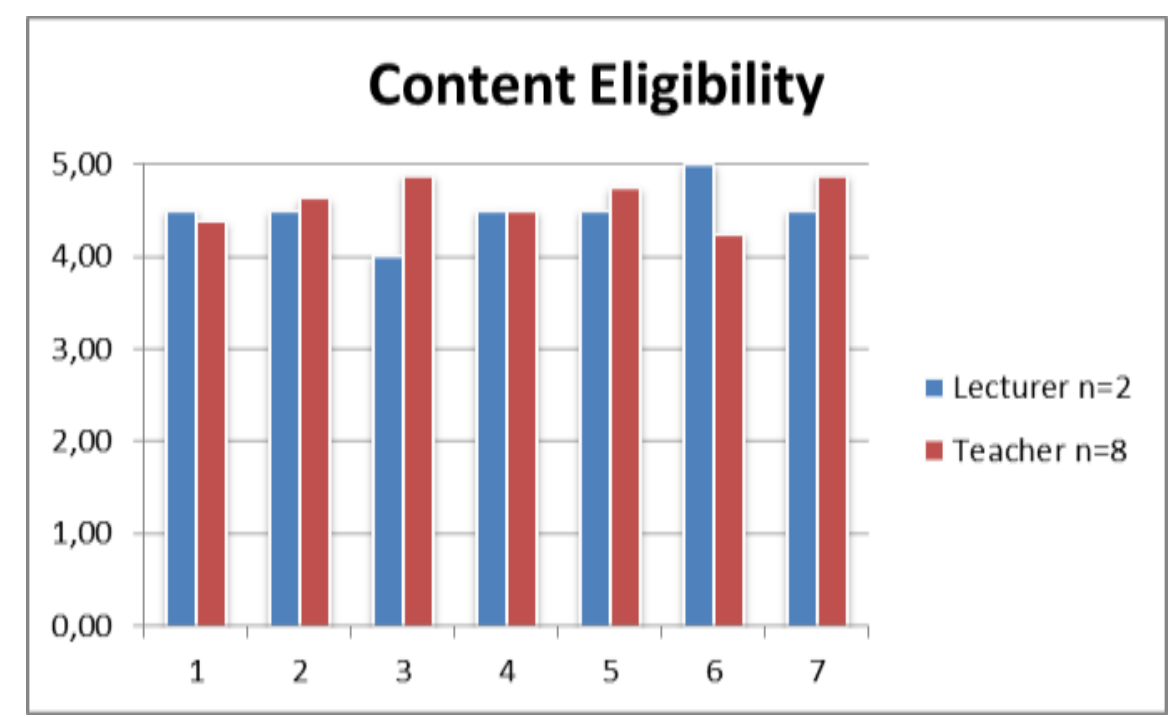

Figure 1. The Results of the Feasibility Test for the Contents of the Innovative Chemistry Lab Guide

\subsection{Serving Feasibility}

The results of the assessment of the chemistry lab guide developed based on K13 on the aspect of the feasibility of serving have an average of 4.61 which is valid, meaning that the product developed is very feasible and does not need to be revised.

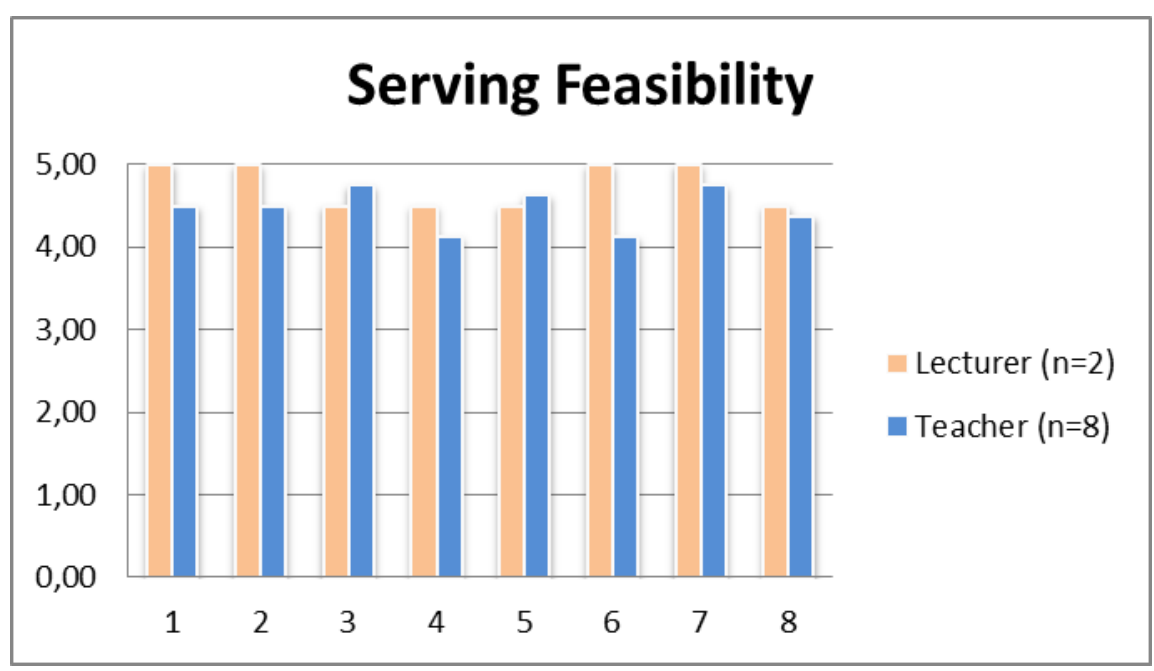

Figure 2. The Feasibility of Presenting an Innovative Chemistry Lab Guide 


\subsection{Material Test}

The results of the assessment of the chemistry lab guide developed based on K13 on the feasibility of the material having an average of 4.53 are valid, meaning that the product developed is very feasible and does not need to be revised.

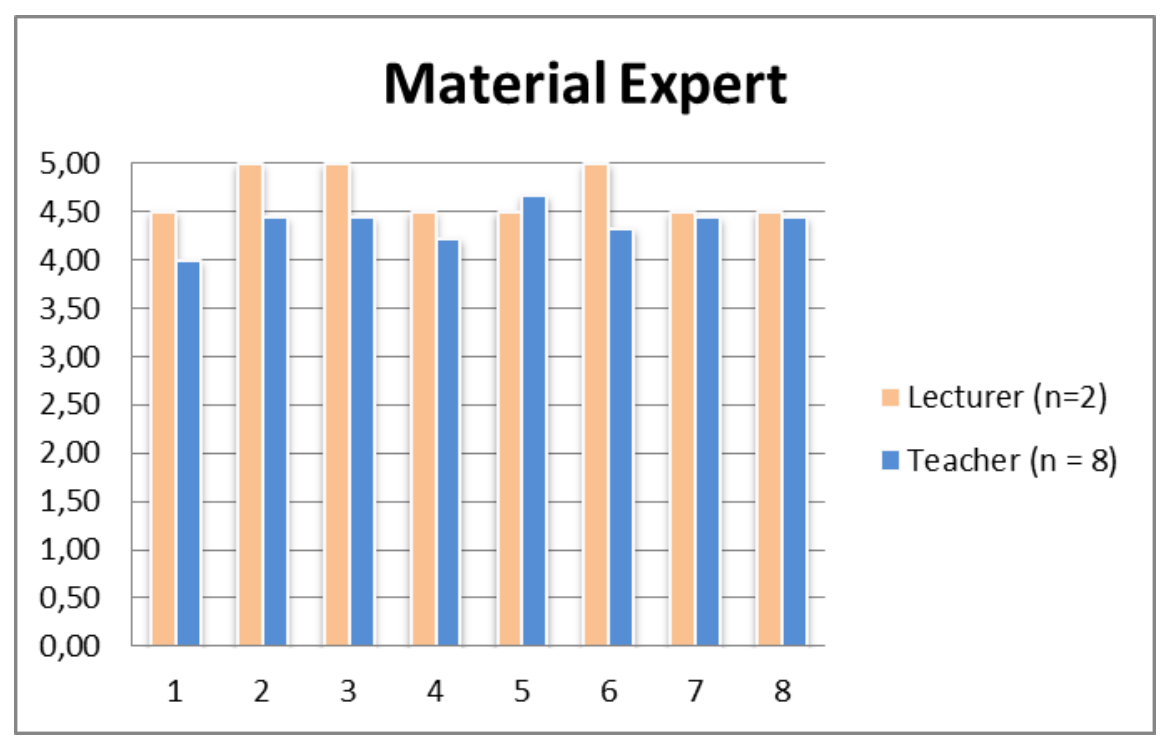

Figure 3. The Average Test Results of the Innovative Chemistry Lab Guide Material

\subsection{Media Expert Test}

The results of the assessment of the chemistry practicum guide developed based on K13 on the feasibility of the material having an average of 4.55 are valid, meaning that the product developed is very feasible and does not need to be revised.

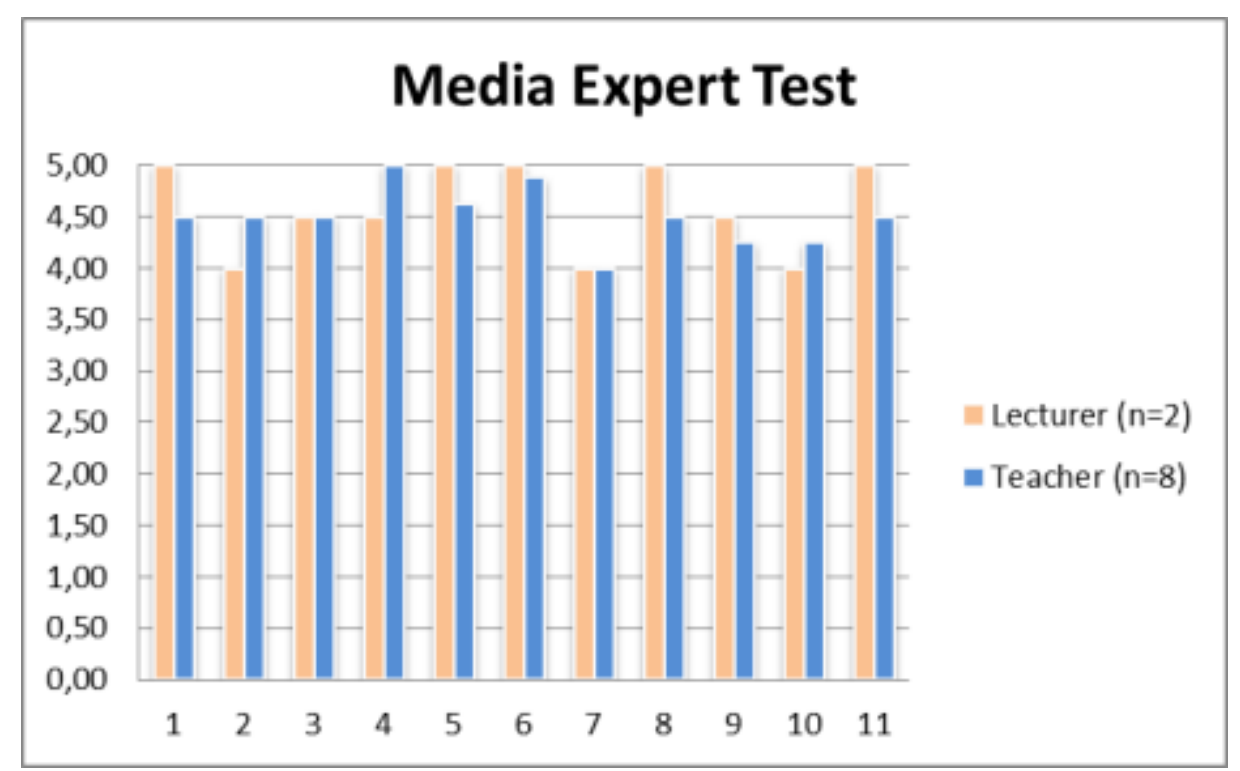

Figure 4. The Average Test Results of the Innovative Chemistry Lab Guide Media

\subsection{Language Expert}

Test The results of the chemistry lab guide assessment developed based on K13 on the feasibility aspect of the material have an average of 4.62 is valid, meaning that the product developed is very feasible and does not need to be revised. 


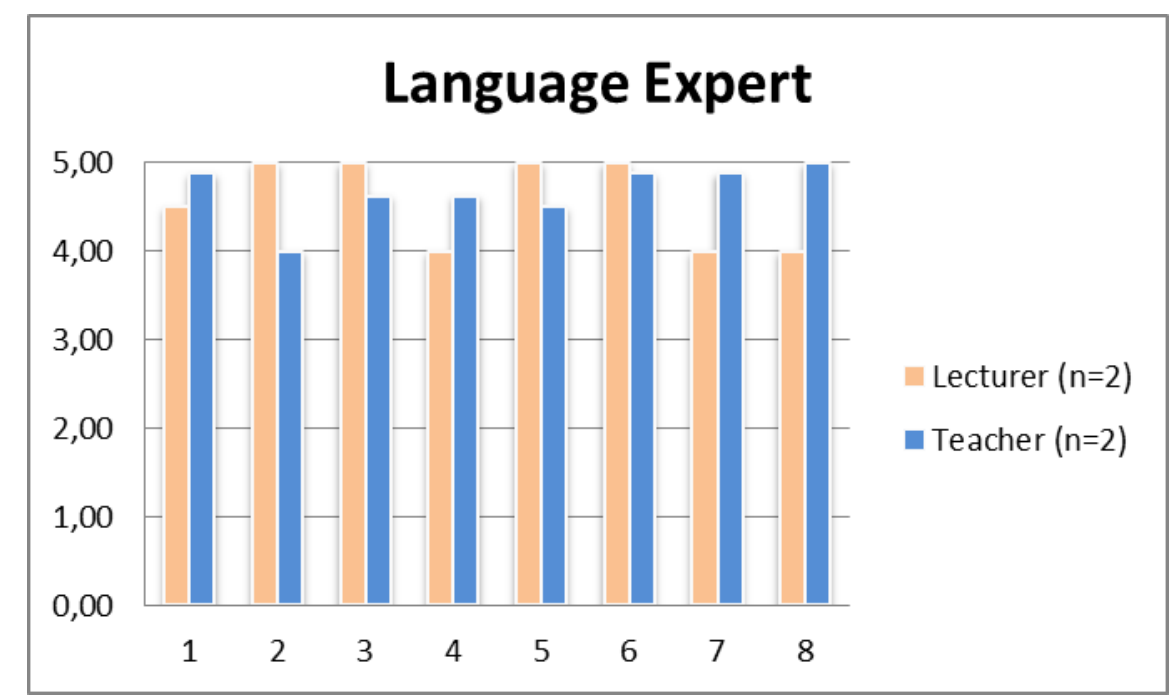

Figure 5. The Average Test Results for the Innovative Chemistry Lab Guide Language

In this study, there were three variables that were observed in the experimental manual guidebook products that had been developed, namely learning outcomes, attitudes, and psychomotics.

\subsection{Learning Outcomes Data}

The next stage the sample is given a posttest to determine the learning outcomes of students after being given different treatments. Finally, the normalized gain (N-Gain) can be determined with the aim of knowing how much improvement in learning outcomes is obtained after being given different treatments. The following is the pretest, posttest, and normalized gain data from the two samples (experimental class and control class) which are summarized in table 1.

Table 1. Prestes, Posttest, and Gain Data Are Normalized

\begin{tabular}{|l|c|c|c|c|c|c|}
\hline \multirow{2}{*}{ Class } & \multicolumn{2}{|c|}{ Prestes } & \multicolumn{2}{c|}{ Posttest } & \multicolumn{2}{c|}{ N-Gain } \\
\cline { 2 - 7 } & $\overline{\boldsymbol{x}}$ & $\mathbf{S}$ & $\overline{\boldsymbol{x}}$ & $\mathbf{S}$ & $\overline{\boldsymbol{x}}$ & $\mathbf{S}$ \\
\hline Experiment & 3,26 & 1,34 & 0,22 & 0,99 & 0,75 & 0,08 \\
\hline Control & 4,35 & 1,71 & 0,22 & 0,46 & 0,61 & 0,08 \\
\hline
\end{tabular}

The table above shows that the mean score of the pretest results of students for the experimental class was 23.36 with a standard deviation of 11.34, and the average for the control class was 24.35 with a standard deviation of 11.71. After being given different treatments, the posttest results were higher than the previous pretest results, namely an average of 80.22 with a standard deviation of 6.99 for the experimental class and an average of 70.22 with a standard deviation of 7.46 for the control class.

\subsection{Attitude Value Result Data}

This attitude value data was obtained by using the student's attitude observation sheet filled out by the observer. Data from the observation of attitude assessment for the experimental class are obtained in table 2. 
Table 2. Attitude Assessment Observation Data

\begin{tabular}{|l|c|c|}
\hline \multicolumn{1}{|c|}{ Data } & Average value & Standard de viation \\
\hline Before treatment & 8.87 & 1.60 \\
\hline After treatment & 14.70 & 1.52 \\
\hline
\end{tabular}

Table 2 shows that the average attitude score before using the developed practicum guide was 8.87 and the mean value of the attitude of the students after using the practicum guide developed was 14.70 .

\subsection{Psychomotor Value Result Data}

To find out activities during the experiment using an innovative chemistry practicum guide based on integrated multimedia values of character education, observations were made along with notes on the psychomotor of students using observation sheets. The psychomotor observation data of students can be seen in table 3 .

Table 3. Observation Data of Psychomotor Values

\begin{tabular}{|l|c|c|}
\hline \multirow{2}{*}{ Aspects Observed } & \multicolumn{2}{|c|}{ Percentage of Observation Sheet Score } \\
\cline { 2 - 3 } & Experiment Class & Control Class \\
\hline Practical preparation & 84.35 & 76.52 \\
\hline Practical implementation & 75.65 & 49.57 \\
\hline End of experiment & 69.57 & 49.57 \\
\hline
\end{tabular}

Table 3 shows that the average percentage score of experimental class students is higher than the control class in the three aspects observed in the process of product trials that have been developed.

\section{Conclusion}

1. An innovative chemistry practicum guide based on multimedia for class XI Semester II integrated character education according to the 2013 curriculum is categorized as valid and suitable for use.

2. The developed practicum guide can develop the character education values of students, this can be seen from the increase in the value of students' attitudes before and after using an innovative chemistry lab guide based on multimedia for class XI Semester II integrated character education according to the 2013 curriculum.

3. There are differences in the learning outcomes of students who use an innovative chemistry practicum guide based on multimedia high school grade XI Semester II integrated character education according to the 2013 curriculum with students who use the handbook chemistry lab guide.

4. There are differences in the attitude (character) and psychomotor (skills) values of students who use an innovative chemistry practicum guide based on multimedia high school grade XI Semester II integrated character education according to the 2013 curriculum with students who use a chemistry lab guide for students. 


\section{References}

Akere J.A. \& Afolabi A.F., 2012. Effect of Video on the Teaching of Library Studies among Undergraduates in Adeyemi College of Education, Ondo. Library Philosophy and Practice (e-journal): University of Nebraska - Lincoln.

Anggraini, Fitri. 2016. Development of Innovative and Interactive High School Practicum Guides Integrated Discovery Learning (Invention Learning) on Elemental Chemistry. Postgraduate Program Universitas Negeri Medan: Medan

Arends, I.A. 2008. Learning To Teach. Diterjemahkan oleh Soetjipto, PH dan Soetjipto,MS. Yogyakarta: Pustaka Belajar.

Borg, W.R., \& Gall M. D. 1983. Educational Research An Introduction. New York: Longman.

Burewicz, A., \& Miranowicz, N. 1995. Computer assisted chemical experiments, IX School of Chemistry Didactics, Sobieszewo. Department of Chemistry Education, Faculty of Chemistry, Adam Mickiewicz University: Poland.

Christianto, Heru. 2016. Analysis and Development of Multimedia-Based Interactive Practicum Guide for Solution Chemistry in Senior High School. Postgraduate program Universitas Negeri Medan: Medan.

Jahro, I. S. \& Susilawati. 2008. Analysis of the Application of Practicum Methods in Learning Chemistry in Senior High Schools. FMIPA, Department of Chemistry: UNIMED.

Kaimuddin. 2014. Implementation of Character Education in the 2013 Curriculum. UIN Alauddin Makassar: Science Dynamics Vol. 14. No 1.

Nahadi. 2009. The Effectiveness of the Teaching Assessment Ability Provisioning for Prospective Chemistry Teacher Students. Doctoral Dissertation SPS Universitas Pendidikan Indonesia: Bandung.

Nurfajriani \& Dyah, T. R. 2016. Development of a Natural Science Learning Module Based on the 5E Learning Cycle on Additives in Food. Medan: Department of Chemistry, FMIPA, Universitas Negeri Medan, Medan

Prasasti, T.I., Solin, M., and Hadi, W. (2019). The Effectiveness of Learning Media Folklore Text of North Sumatera Based on Blended Learning by 10th Grade Students of Vocational High SchoolHarapan Mekar-1 Medan. Budapest International Research and Critics in Linguistics and Education (BirLE) Journal Vol 2 (4): 480490.

Robbins, Stephens. 1994. Organization Behaviour. Australia: Prentice Hall.

Rogers, E. M. 2003. Diffusion of Innovations. New York: Free Press.

Suparman. 1991. Get to know Artificial Intelligence. Andi Offset, Yogyakarta.

Syakur, A., Fanani, Z., and Ahmadi, R. (2020). The Effectiveness of Reading English Learning Process Based on Blended Learning through "Absyak" Website Media in Higher Education. Budapest International Research and Critics in Linguistics and Education (BirLE) Journal Vol 3 (2): 763-772.

Twelker, P. A., Urbach, F.D., \& Buck, J. E. 1972. The Systematic Development of Instruction: An Overview And Basic Guide To The Literature. United States International University in Oregon Corvallis: Oregon. 